\title{
Levantamento e caracterização da dipterofauna necrófaga em uma localidade de Brasília
}

\author{
Gabriel Alonzo Carreira ${ }^{1}$ \\ Luciano Chaves Arantes ${ }^{2}$ \\ Luzia Helena Correa Lima ${ }^{3}$ \\ Paulo Roberto Queiroz
}

\section{Resumo}

Os dípteros representam um grupo de extrema relevância para a criminalística graças à sua capacidade de encontrar corpos em decomposição, permitindo a estimativa do intervalo post mortem. A dificuldade de identificação dos dípteros é um problema que muitos dos profissionais têm que lidar para obter informações acuradas que possam ser utilizadas como provas de crime. Para resolver esse problema, as identificações por marcadores moleculares se mostram como um método eficiente. O objetivo desse trabalho é descrever a população de dípteros de interesse forense em Brasília por meio de marcadores moleculares baseados em DNA. Os resultados indicaram que marcadores RAPD e de DNAmt podem ser usados para a identificação de Chrysomya albiceps. Sendo assim, estabeleceu-se um método molecular para identificação de uma espécie de interesse forense que poderá servir como auxílio na elucidação de crimes na região ou na identificação de vestígios incompletos ou imaturos de dípteros.

Palavras-chave: Criminalística. Entomologia. Marcadores moleculares.

\footnotetext{
${ }^{1}$ Graduando em Biologia - UniCEUB; e-mail: cranedaimio@yahoo.com.br

${ }^{2}$ MSc Ciências Forenses. King's College London. Perito Criminal do Instituto de Criminalística da Polícia Civil do Distrito Federal; e-mail: lca1969@gmail.com

${ }^{3}$ PhD Biologia Molecular. Universidade de Brasília - UnB. Pesquisadora do Centro Nacional de Recursos Genéticos (CENARGEN),EMBRAPA; e-mail: luzia@cenargen.embrapa.br

${ }^{4} \mathrm{PhD}$ Biologia Animal. Universidade de Brasília - UnB. Professor do curso de Biologia UniCEUB; e-mail: pqsilva@uol.com.br
} 


\section{Introdução}

A Entomologia Forense é a disciplina científica que interpreta as informações fornecidas pelos insetos (WOLFF et al., 2001). Estudos de entomologia forense envolvem todo e qualquer inseto que se relacione com cadáveres provenientes de crimes. Dentre esses insetos, os mais comumente encontrados em cenas de crime são os dípteros da família Calliphoridae. Em virtude do seu comportamento de oviposição em carcaças e vísceras em decomposição, os Calliphoridae são considerados importantes indicadores criminalísticos do tempo transcorrido desde a morte (VIANNA et al., 2004). Sendo assim, espécies da família Calliphoridae estão entre as mais utilizadas em análises forenses. Os adultos dessas espécies de moscas podem apresentar distribuição espacial e temporal extremamente específicas. Além disso, Calliphoridae também responde singularmente a corpos em diferentes estágios de decomposição (STEVENS; WALL, 2001).

Os estágios de desenvolvimento dos ovos e larvas também são extremamente previsíveis, sendo altamente influenciados pela temperatura e, em um grau menor, pela umidade relativa do ar. Um conhecimento detalhado da biologia de várias espécies de dípteros e sua sucessão em um corpo em decomposição pode prover importantes informações a respeito do local e do tempo de morte (TURCHETTO et al., 2001; GRASSBERGUER; REITER, 2002a). Uma das principais aplicações da entomologia forense se dá na determinação do intervalo post mortem (IPM), que é definido como o intervalo de tempo transcorrido entre a morte do indivíduo e a descoberta do corpo. Para encontrar esse intervalo, os peritos podem se valer da rigidez cadavérica, do resfriamento do corpo, dos livores cadavéricos, das diferentes fases de decomposição e, por fim, da fauna cadavérica (BENECKE, 2001). Nos métodos tradicionais, a estimativa do IPM e sua acurácia são inversamente proporcionais, isto é, quanto maior for o IPM menor é a possibilidade de acurada determinação. Porém, com o auxílio de conhecimentos entomológicos é possível obter estimativas de IPM com razoável precisão, mesmo meses após a morte. Vários métodos entomológicos são utilizados para determinar o IPM de corpos, entre eles, os principais são: a determinação do estágio de desenvolvimento das fases imaturas de insetos e a sucessão de diferentes espécies e grupos de insetos na colonização do cadáver. Vale salientar que os estágios de desenvolvimento de dípteros são influenciados 
pelas condições do local, como temperatura e umidade (GRASSBERGER; REITER, 2001). A sucessão cadavérica consiste na análise da fauna necrófaga de um corpo de acordo com seus os estágios de decomposição. A fauna de artrópodes que sucede um corpo varia de acordo com o estágio de decomposição, pois cada estágio oferece condições ideais para o desenvolvimento de certas espécies de artrópodes, mas não de outras. A grande maioria dos autores utiliza carcaças de suínos como modelo experimental; mas, estudos com humanos, ratos, cães ou mesmo partes separadas de animais como, fígado ou carne de origem bovina, já foram utilizados para medir, não somente a sucessão cadavérica, como também o IPM (MARCHENKO, 2001).

Para que tais estudos entomológicos sejam válidos e aceitos pela lei, fazse necessário que a identificação dos indivíduos encontrados seja extremamente precisa. Entretanto, a identificação dos espécimes por meios morfológicos muitas vezes é dificultada ou até mesmo impossível, particularmente, quando as amostras estão pouco preservadas ou os indivíduos ainda estão em seus estágios larvais (STEVENS; WALL, 2001). A identificação de larvas de dípteros ou partes delas é um problema para aqueles que trabalham na área, pois há certa dificuldade em se identificar todos os estágios de maturação de certos dípteros e, até o presente momento, não há chaves de identificação que cubram todos os estágios larvais de todos os dípteros de interesse forense. Além disso, há também o problema das amostras estarem em más condições, com partes anatômicas faltando ou deformadas. Nessas condições, torna-se quase impossível sua identificação por meio dos métodos taxonômicos tradicionais, pois estes se baseiam em características únicas e muito específicas de cada espécie de díptero (WELLS; SPERLING, 2001).

Uma alternativa para esse problema é a identificação dos dípteros por meio de marcadores moleculares espécie-específicos. Um marcador de DNA específico é capaz de identificar um espécime em qualquer estágio de maturação ou até mesmo se a amostra não estiver íntegra, contendo apenas partes do animal coletado (MALGORN; COQUOZ, 1999; WELLS; SPERLING, 2001). Uma das técnicas utilizadas para a identificação de dípteros de interesse forense é o Random Amplified Polymorphic DNA (RAPD). Essa metodologia consiste na variação da técnica de PCR, utilizando-se um iniciador de sequência aleatória e 
curta que se ligará a sequências complementares encontradas dispersas ao longo do genoma do indivíduo e que a amplificará, gerando uma série de fragmentos de DNA. Uma das características dessa estratégia consiste na obtenção de sequências amplificadas aleatoriamente pela PCR, gerando um padrão molecular único para cada indivíduo. Essa metodologia também é capaz de identificar indivíduos de uma mesma espécie por meio da semelhança nos fragmentos de DNA que foram amplificados, pois, mesmo com grandes polimorfismos, ainda existem regiões que não sofrem grandes alterações, mantendo-se constantes dentro de uma espécie (GRIFFITHS et al., 2001). Estudos de identificação de dípteros de interesse forense, utilizando-se a técnica de RAPD, mostraram-se eficientes, tornando a técnica de fácil implementação na obtenção de perfis eletroforéticos de DNA relacionados à família Calliphoridae. Por outro lado, a alta suscetibilidade a mudanças nos padrões da reação e às variações de temperaturas no termociclador podem gerar diferenças nos resultados (BENECKE, 1998; KULSHRESTHA; SATPATHY, 2001).

Como solução aos problemas associados à técnica de RAPD, foi proposta a utilização do DNA mitocondrial para a identificação molecular. O menor tamanho do DNAmt, sua forma circular e a proteção das duas membranas mitocondriais fazem com que ele tenha uma maior estabilidade, sendo possível a obtenção de informação genética de indivíduos em precário estado de conservação, ou até mesmo conservados em etanol (WALLMAN; DONNELLAN, 2001; JUNQUEIRA et al., 2004). Dentro do DNAmt existem genes conservados que expressam uma enorme quantidade de proteínas, entre elas a citocromo oxidase, uma proteína que faz parte do complexo de transporte de elétrons da cadeia respiratória. A falta dessa proteína causa erros na respiração celular e morte do indivíduo (HARVEY et al., 2003; MIRA; VIEIRA, 2006). Por causa de suas características, o gene da citocromo oxidase é conservado e muito utilizado em técnicas moleculares para a obtenção de marcadores característicos de populações ou espécies; ou seja, iniciadores específicos para este gene são criados, utilizandose da técnica de PCR, padrões de bandas característicos podem ser avaliados (WELLS; SPERLING, 2001).

Todas as técnicas acima mostradas têm sido usadas para a identificação de espécies ou mesmo de populações de dípteros de interesse forense com re- 
sultados positivos. Wallman e Donnellan (2001) conseguiram caracterizar com sucesso populações de Calliphoridae na Austrália, utilizando o gene da citocromo oxidase, identificando populações distintas de dípteros e seus parentescos. O mesmo acontece com as espécies de califorídeos da subfamília Chrysomyinae originárias do Canadá e EUA. Os procedimentos de análise são parecidos e ambos utilizaram os genes da citocromo oxidase em seus experimentos (WELLS; SPERLING, 2001).

No Brasil, em função da extremamente elevada biodiversidade e da presença de espécies endêmicas, acredita-se que a caracterização molecular para a identificação das principais espécies de insetos de interesse forense poderá contribuir com o desenvolvimento da Entomologia Forense no país.

Sendo assim, o objetivo deste estudo é descrever o comportamento de uma população de dípteros de interesse forense presente em uma região residencial de Brasília, como também, identificar dentro dessa população indivíduos de C. albiceps por meio de marcadores moleculares baseados em DNA.

\section{Material e métodos}

\subsection{Montagem de armadilha, utilizando material reciclável do tipo PET}

Para a coleta dos insetos de interesse forense foi utilizada uma armadilha construída a partir de duas garrafas transparentes do tipo PET de 2,5 L.

\subsection{Coleta dos insetos de interesse forense}

Para a coleta dos dípteros de interesse forense foi mantida a armadilha pendurada a 1,5 m de altura a partir do solo sob a ação parcial do sol (durante 6 horas). A área de estudo foi constituída por um terreno localizado no Lago Norte, nas coordenadas $15^{\circ} 44^{\prime} 10.28^{\prime \prime}$ sul e $47^{\circ} 51^{\prime} 06.65^{\prime \prime}$ oeste. Utilizou-se como isca, aproximadamente, $100 \mathrm{~g}$ de carne bovina moída, sendo depositada em pote descartável de plástico de $100 \mathrm{ml}$ que foi posicionado na antecâmara da armadilha. A armadilha ficou situada na área de coleta durante um período de 30 dias, sendo retiradas amostras em períodos de $24 \mathrm{~h}$. Os insetos foram coletados 
por meio da abertura superior e foram armazenados diretamente em um saco plástico com fecho hermético. Após a retirada dos espécimes vivos, a armadilha foi desmontada sobre uma folha de papel cartão e os insetos mortos foram recolhidos para o mesmo saco plástico que recebia uma etiqueta de papel escrita a lápis, indicando a data da coleta. As amostras foram transferidas então para potes herméticos, contendo etanol $70 \%$. Depois disso, a armadilha foi remontada e recolocada em seu lugar de origem. A mesma isca foi utilizada na armadilha durante todo o período de captura.

Ao final do período de coleta, as amostras em álcool foram levadas ao laboratório e os indivíduos foram identificados, separados e contados por família com o uso de uma lupa estereoscópica e de uma chave dicotômica para a identificação de famílias de Diptera (BORROR; DELONG, 1969).

\subsection{Extração de DNA}

Para os estudos de caracterização molecular, o DNA de indivíduos pertencentes à família Calliphoridae foi extraído a partir de um método previamente estabelecido (QUEIROZ et al., 2004), seguindo-se adaptações dos protocolos de Agusti et al. (1999) e Monnerat et al. (2004). Submeteu-se um inseto inteiro à maceração e, a seguir, adicionou-se $500 \mathrm{~mL}$ de tampão de extração (Tris-HCl $10 \mathrm{mM}$ pH 8, EDTA 1 mM, Triton X-100 0,3 \% e Proteinase K 120 mg.mL ${ }^{-1}$ ), incubandose por $60 \mathrm{~min}$ a $65{ }^{\circ} \mathrm{C}$. O homogenado foi centrifugado por $10 \mathrm{~min}$ a $10.000 \mathrm{xg}$ , e o sobrenadante, transferido para um tubo plástico. Adicionou-se $500 \mathrm{~mL}$ de fenol/clorofórmio/álcool isoamílico (25:24:1) e as fases foram homogeneizadas em vortex por $5 \mathrm{~s}$. O material foi centrifugado por $10 \mathrm{~min}$ a $10.000 x g$ a $10^{\circ} \mathrm{C}$. A fase aquosa foi então transferida para um novo tubo plástico, repetindo-se a etapa anteriormente descrita.

O DNA foi precipitado pela adição de $30 \mathrm{~mL}$ de $\mathrm{NaCl} 5 \mathrm{M}$ e $1 \mathrm{~mL}$ de etanol absoluto, incubando-se por $16 \mathrm{~h}$ a $-20^{\circ} \mathrm{C}$. Após centrifugação a $10.000 x g$ por 10 min a $10^{\circ} \mathrm{C}$. O DNA precipitado foi lavado duas vezes com $500 \mathrm{~mL}$ de etanol 70 \%, seco a vácuo, ressuspenso em TE 0,1 X (Tris- $\mathrm{HCl} 1 \mathrm{mM}$ pH 8, EDTA 0,1 mM) e armazenado a $-20^{\circ} \mathrm{C}$ até o momento do uso. 


\subsection{Reação de RAPD}

Para os estudos de caracterização molecular, O DNA extraído (100 ng.mL-1), a partir de indivíduos da família Calliphoridae, foi utilizado em $30 \mathrm{~mL}$ de uma reação de RAPD, contendo tampão (Tris- $\mathrm{HCl} 6 \mathrm{mM} \mathrm{pH} \mathrm{8,8,} \mathrm{KCl} 50$ mM e $\mathrm{MgCl}_{2} 2$ $\mathrm{mM}$ ), dNTP's $0,2 \mathrm{mM}, 0,4 \mathrm{mM}$ do primer de sequência aleatória OPA-13 (5'CAGCACCCAC3') (Operon Technologies, Inc.), 2,5 U.mL ${ }^{-1}$ de Taq DNA polimerase (Pharmacia) e $5 \mathrm{~mL}$ de DNA, conforme descrições da metodologia descrita por Lima et al. (2000).

\subsection{Ciclos de amplificação de RAPD}

As amplificações foram efetuadas em termociclador (PTC 100 MJ Research), programado para 45 ciclos, contendo uma etapa inicial de desnaturação de 3 min a $94{ }^{\circ} \mathrm{C}$. Cada ciclo foi constituído de uma etapa de desnaturação de 1 min a $93{ }^{\circ} \mathrm{C}$, anelamento por $1 \min$ a $35^{\circ} \mathrm{C}$ e extensão por $2 \min$ a $72^{\circ} \mathrm{C}$. Após os ciclos, foi realizada uma etapa de extensão final de $5 \min$ a $72{ }^{\circ} \mathrm{C}$.

\subsection{Reações de PCR utilizando DNA Mitocondrial}

As reações de amplificação foram realizadas em $25 \mu \mathrm{L}$ de uma mistura contendo $11,1 \mu \mathrm{L}$ de água milliQ autoclavada, $2,5 \mu \mathrm{L}$ de tampão $10 \mathrm{X}$ (Amersham), $1,5 \mu \mathrm{L}$ de cada primer (IDT, Inc., Coralville, IA) na concentração de $10 \mu \mathrm{M}, 0,5 \mu \mathrm{L}$ dNTP 10 mM, 0,4 $\mu \mathrm{L}$ Taq DNA polimerase (Amersham) 1 U. $\mu \mathrm{L}^{-1}$ e 5,0 $\mu \mathrm{L}$ de DNA (100 ng).

\subsubsection{Condições de Amplificação para o PCR Mitocondrial}

As amplificações foram efetuadas em termociclador (PTC-100 MJ Research) contendo uma etapa inicial de desnaturação de 3 min a $94{ }^{\circ} \mathrm{C}$, programado para 35 ciclos de desnaturação de 1 min a $94{ }^{\circ} \mathrm{C}$, anelamento por $1 \mathrm{~min}$ a $48{ }^{\circ} \mathrm{C} \mathrm{e}$ extensão por 1 min a $72{ }^{\circ} \mathrm{C}$ e uma etapa final de extensão de 5 min a $72{ }^{\circ} \mathrm{C}$ conforme metodologia descrita por Harvey et al. (2003). 


\subsubsection{Visualização dos Fragmentos Resultantes de PCR}

Os produtos de amplificação foram visualizados em gel de agarose 1,5 \% submerso em tampão TBE 1 X (Tris-borato $9 \mathrm{mM}$ e EDTA $1 \mathrm{mM}$ ), fotografados e arquivados no sistema Eagleeye. Em todos os géis, marcadores de massa molecular (Ladder 100 bp - GIBCO) foram usados para a determinação do tamanho dos fragmentos amplificados. A visualização das bandas foi feita por imersão em solução corante contendo $1 \mu \mathrm{g} \cdot \mathrm{mL}^{-1}$ por $30 \mathrm{~min}$, seguindo-se a retirada do excesso de corante em água destilada por $30 \mathrm{~min}$.

\section{Resultados}

Após um período de trinta dias contínuos de captura, foram coletados 1116 dípteros pertencentes a várias famílias. Durante esse período, observou-se variação quanto à quantidade de insetos coletados (Figura 1).

Observou-se durante a realização do experimento pouca variação nos índices de temperatura ao longo do período de coleta. Essa variação ficou em 26,13

Figura 1 - Distribuição de dípteros de interesse forense, coletados ao longo de 30 dias de coleta com monitoramento de temperatura.

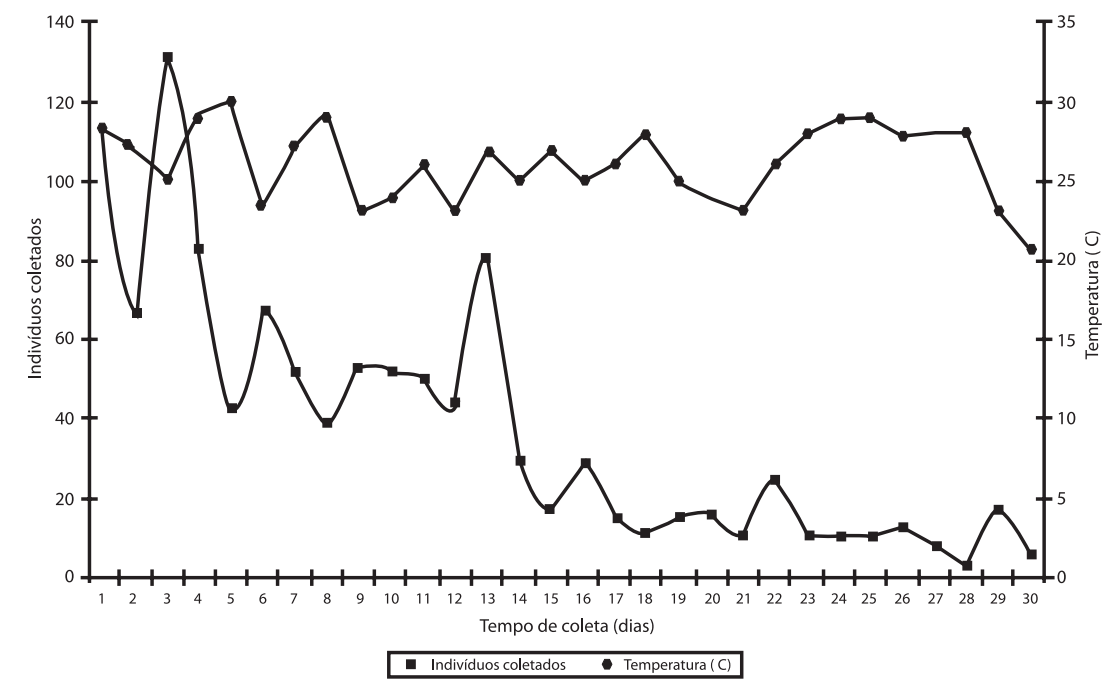


${ }^{\circ} \mathrm{C} \pm 2,32$ entre os dias de coleta. As maiores variações de temperatura foram verificadas em dias de chuva. Chuvas ocasionais foram comuns nesse período, mas, na maioria dos dias de coleta, as condições climáticas variaram de céu aberto a nublado.

O levantamento da entomofauna produziu uma curva de distribuição sendo que, grande parte dos dípteros foi atraída pelos primeiros estágios de decomposição da isca. De acordo com a progressão da decomposição, houve um pico populacional por volta do terceiro dia, provavelmente causado pela formação de um ambiente ideal, com temperatura e estágio de decomposição adequados, uma vez que as temperaturas nesse período ficaram entre $29^{\circ} \mathrm{C}$ a $30^{\circ} \mathrm{C}$, sendo mais elevadas durante os dias de coleta. Após o quinto dia de coleta ocorreu um decréscimo no número de indivíduos capturados. Provavelmente, isso se deve às condições de dessecação e ao avançado estágio de decomposição da dieta, tornando-a inadequada à oviposição de certas famílias de dípteros e à redução da atratividade da isca.

Das principais famílias de dípteros de interesse forense, foram encontrados 406 indivíduos da família Muscidae, 58 da família Sarcophagidae e apenas 26 da família Calliphoridae. Essas principais famílias de dípteros de interesse forense apresentaram flutuação populacional durante os trinta dias de coleta (Figura 2).

Figura 2 - Distribuição das principais famílias de dípteros de interesse forense ao longo dos trinta dias de coleta.

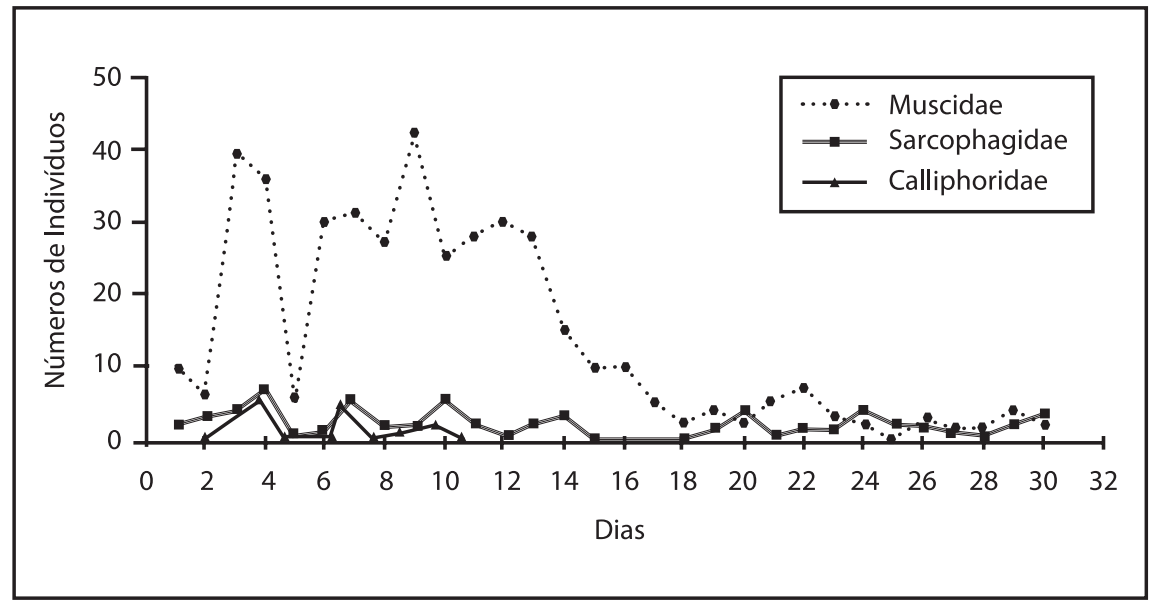


Observou-se que dípteros da família Muscidae apresentaram maior quantidade de indivíduos em relação à Calliphoridae e Sarcophagidae. Além disso, Calliphoridae e Sarcophagidae apresentaram o mesmo comportamento ao longo do experimento, capturando-se, no máximo, cinco indivíduos de cada uma dessas famílias para cada dia de coleta. Para Muscidae, observou-se um comportamento diferente em relação à Calliphoridae e Sarcophagidae. O ápice de atividade dessa família ficou entre o segundo e o décimo oitavo dias de coleta. Após o décimo quarto dia, observou-se declínio acentuado dessa família, ficando em níveis de coleta comparáveis às demais famílias analisadas nesse estudo, não sendo encontrada explicação para esta queda drástica nas populações de dípteros. Foi realizada uma comparação com a temperatura, mas esta não demonstrou padrão ou qualquer relação com o fato ocorrido. Supõe-se que fatores relacionados com as condições da isca, seus estágios de decomposição ou mesmo o efeito de dessecamento tenham interferido na capacidade dela em atrair os indivíduos durante o período de realização do experimento.

Ao término das coletas e identificação morfológica dos dípteros, vários indivíduos pertencentes à família Calliphoridae foram selecionados e utilizados nas estratégias moleculares para a análise de DNAmt. A partir da utilização da chave dicotômica para a identificação de famílias e espécies de Diptera proposta por Borror e Delong (1969), identificaram-se C. albiceps e C. megacephala. Em virtude da maior quantidade de $C$. albicpes nas coletas, optou-se por essa espécie para os estudos moleculares. A partir da adaptação dos iniciadores propostos por Harvey et al. (2003) obteve-se um produto de amplificação para essa espécie de Diptera (Figura 3).

Figura 3 - Gel de agarose 1,5 \% corado com brometo de etidio identificando os fragmentos de DNA correspondentes ao gene da citocromo oxidase I de Calliphoridae da espécie C. albiceps. 0 marcador de massa molecular utilizado foi o 100 pb Ladder.

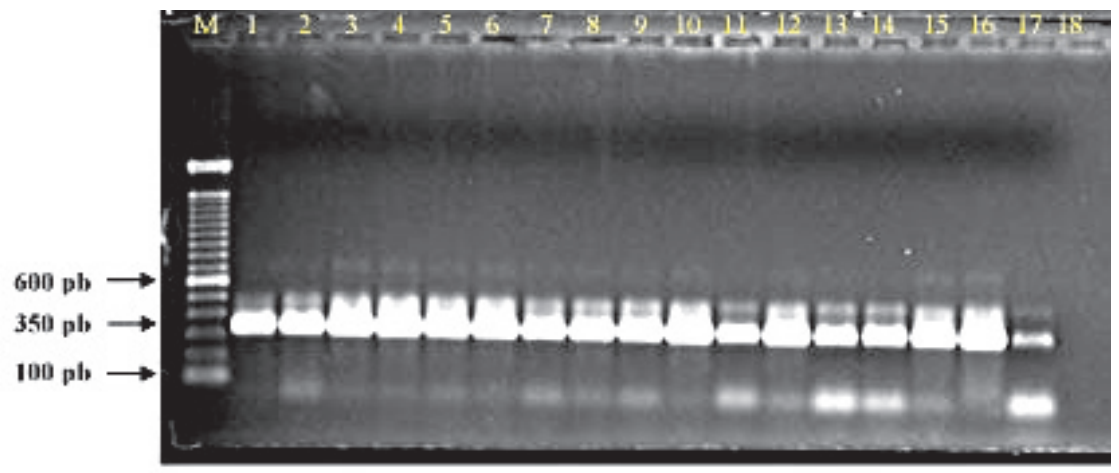


Conforme o esperado, o iniciador utilizado para a identificação de Calliphoridae na Austrália por Harvey et al. (2003) se ligou ao gene mitocondrial da citocromo oxidase I dos indivíduos selecionados nesse estudo e produziu um fragmento de aproximadamente 350 pb. Esta identificação por DNAmt confirmou os dados da identificação taxonômica pelo critério morfológico. Esse resultado demonstra o potencial de se utilizar marcadores de DNAmt como ferramentas auxiliares na identificação morfológica de dípteros da família Calliphoridae, tornando assim essas identificações muito mais precisas, permitindo a identificação de insetos de interesse forense, mesmo quando estes não se encontram em condições adequadas de conservação ou quando se tem apenas vestígios dos mesmos.

Após a análise por DNAmt, as amostras de C. albiceps foram analisadas pelo método de RAPD, no qual foram visualizados diferentes perfis eletroforéticos (Figura 4).

Ao serem aplicadas no gel a reação de RAPD, a partir de amostras de insetos da família Calliphoridae, supôs-se que todas as amostras identificadas morfologicamente eram de indivíduos da espécie C. albiceps. Como esperado, o gel, ao ser visualizado em luz UV, demonstrou um perfil de fragmentos de DNA com grande quantidade de polimorfismos entre os indivíduos. Entretanto, um fragmento de aproximadamente $580 \mathrm{pb}$ mostrou-se presente em todos os indivíduos, exceto o

Figura 4 - Gel de agarose 1,5\% corado com brometo de etidio demonstrando as bandas amplificadas pelo método de RAPD. Os códigos de B1 a D5 representam os vários indivíduos da família Calliphoridae. $O$ marcador de massa molecular foi o 100 pb Ladder. A seta azul indica o fragmento de DNA de $\mathbf{5 8 0}$ pb presente nas amostras de insetos, identificadas como C. albiceps. A seta amarela indica o fragmento de DNA de uma amostra suspeita de não ser C. albiceps.

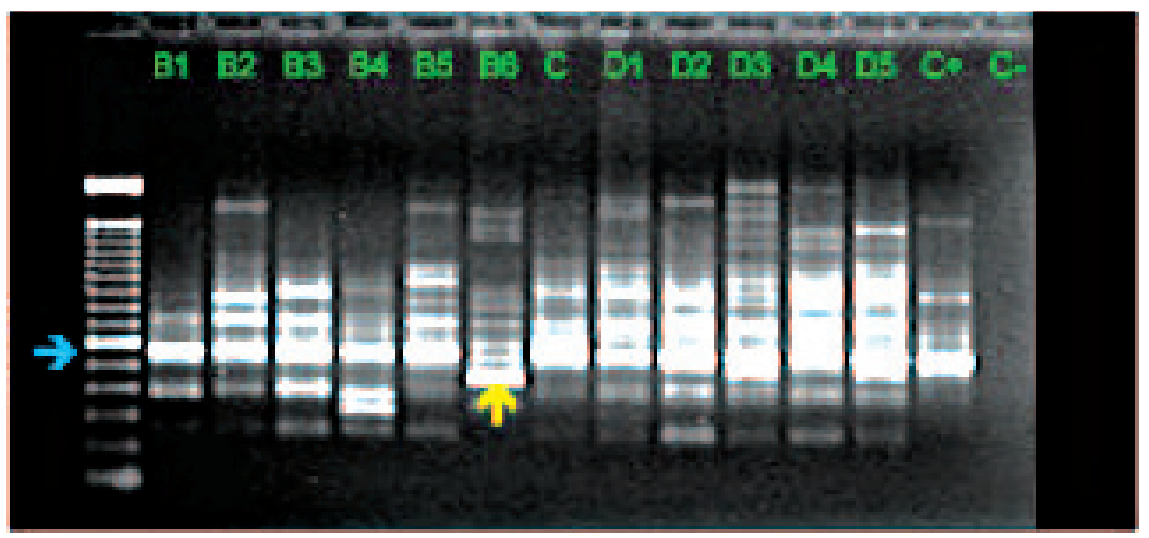


indivíduo de marcação B6 que demonstrou um fragmento de RAPD diferente dos demais dípteros analisados. Com a análise do gel, foi confirmada a hipótese de que todos os indivíduos eram pertencentes à espécie C. albiceps, exceto a amostra B6 que se suspeita ser de outra espécie de Calliphoridae.

\section{Discussão}

A obtenção de uma rotina de captura eficiente para a coleta de dípteros de interesse forense é de grande importância para que haja uma padronização nos estudos de populações de artrópodes no Brasil. O estudo mostrou a eficiência da rotina testada, demonstrando que esta pode vir a ser futuramente utilizada como padrão para estudos de entomofauna de interesse forense. A armadilha feita com material reciclável do tipo PET mostrou-se eficiente, mantendo os insetos sob contenção na antecâmara durante a janela de coleta. Dessa forma, estabeleceu-se uma técnica para a montagem de uma armadilha feita a partir de material reciclável, resultando em baixo custo operacional.

A isca feita de carne moída apresentou um comportamento diferente do esperado, tendo seus estágios de putrefação retardados e com a formação de uma camada ressecada em sua superfície. Entretanto, as porções interiores ainda se apresentavam umedecidas e em estágio de decomposição. Essa característica possibilitou que a isca demorasse mais que o esperado para se decompor, ficando ativa por um maior período de tempo. Maiores estudos poderão ser feitos, buscando-se as melhores combinações e condições para que a dieta fique ativa e simule os estágios de decomposição dentro da armadilha ao longo da realização do experimento.

Além disso, Vianna et al. (2004), em um estudo de populações de Calliphoridae constataram que temperaturas na faixa de $23{ }^{\circ} \mathrm{C}$ são ideais para o crescimento de populações de dípteros, mas seu estudo foi feito em regiões mais úmidas, onde a variação térmica apresentou-se diferente. A alta temperatura na região do Cerrado com a sua baixa umidade relativa do ar podem ser fatores determinantes na dinâmica das populações que são atraídas até a armadilha. A importância da temperatura na dinâmica das populações de dípteros foi constatada por Grassberger \& Reiter (2002) que mencionaram que a flutuação populacional no ambiente natural é influenciada por fatores abióticos e bióticos, sendo os abi- 
óticos mais importantes enquanto os bióticos exercem apenas papel secundário. Outro fator que pode ter exercido influência na coleta dos dípteros foi o fato de que a isca utilizada apresentou alterações em sua superfície. Uma vez contida em um pequeno pote, a isca formou, com o passar dos dias, uma pequena camada de carne dessecada em sua superfície enquanto o resto da dieta continuou a se decompor, em um processo mais lento, por baixo dessa camada dessecada. Esse comportamento da dieta pode ser um fator limitante na obtenção dos dípteros, uma vez que estes ainda eram atraídos pela armadilha, mas não sendo observada a oviposição. Isso pode ser devido ao fato de que as metodologias de uso da armadilha e de coleta de insetos são diferentes das normalmente utilizadas por outros autores que empregam carcaças de animais mortos.

O fato da colocação da armadilha em uma área urbana revelou a alta densidade populacional da família Muscidae em relação às outras famílias que foram coletadas na armadilha. O fato de a família Muscidae ser cosmopolita e de predominância em áreas urbanas pode ser o fator responsável pelo seu aparecimento em quantidade na armadilha. Essa predominância de Muscidae pode vir a ser utilizada como característica especial da região para um marcador de local de crime já que muitos autores, entre eles Oliveira-Costa (2003), descrevem a principal família de dípteros atraída por corpos como sendo os Calliphoridae, diferente dessa região que apresenta uma predominância de Muscidae, seguido pelos Calliphoridae e, por fim, Sarcophagidae.

A análise molecular utilizando marcadores baseados em DNA, tais como os de RAPD, revelou um fragmento comum entre os indivíduos analisados. Esse fragmento de 580 pares de bases encontrado na análise em todos os indivíduos da espécie C. albiceps foi considerado uma "banda candidata", pois pode vir a ser um fragmento de identificação específica da espécie. Futuras análises ainda serão feitas e, se realmente for constatado que esse fragmento aparece em todos os indivíduos dessa espécie, ela poderá ser futuramente sequenciada e iniciadores de PCR específicos para ela poderão ser desenvolvidos, criando-se assim um kit de identificação espécie-específico para C. albiceps. Harvey et al. (2003) demonstraram em seu estudo que a falta de iniciadores de PCR específicos para artrópodes de interesse forense é um entrave para a correta identificação de alguns dípteros, tais como, os Sarcophagidae, que apresentam muitas espécies compartilhando alta similaridade 
morfológica. Mesmo a técnica de RAPD, fornecendo informações distintas entre as espécies de dípteros por meio de perfil de fragmentos de DNA, não é capaz de identificar um indivíduo sem uma base de referência. Sendo assim, a conversão de marcadores de RAPD em reações de PCR é uma estratégia importante para a identificação de insetos de interesse forense. Dessa forma, o emprego da técnica de PCR, que utiliza oligonucleotídeos para cada espécie, seria capaz de identificar indivíduos sem a necessidade de referência ou até mesmo identificação morfológica. Isso demonstra a importância da obtenção de iniciadores específicos para a identificação de artrópodes, sobretudo, os de relevância em questões forenses.

\section{Evaluation and characterization of the necrophagous dipterofauna occuring in Brasilia, Brazil}

\section{Abstract}

Diptera represents an extremely important class of insects for the forensic science. Representatives of some Diptera families are capable of finding corpses within hours after death allowing post mortem interval evaluations. Unfortunately, species identification of these insects is still difficult and taxonomists are not always available. To solve or reduce this situation, the identification of these insects by molecular markers is an efficient and recognized method. The objective of this work was to describe one population of the blowfly Chrysomya albiceps (Diptera) occurring in Brasília by molecular markers based in DNA. The results indicated that RAPD and mtDNA can be used to identify C. albiceps. These molecular methods of detection of $C$. albiceps will be useful to help elucidating crimes in Brasília and to identify immature forms of this fly species.

Keywords: Forensic. Entomology. Molecular markers.

\section{Referências}

AGUSTI, N.; DE VICENTE, M.C.; GABARRA, R. Development of sequence amplified characterized region (SCAR) markers of Helicoverpa armigera: a new polymerase chain reaction-based technique for predator gut analysis. Molecular Ecology, [S.1], n. 8, p. 1467-1474, 1999. 
BENECKE, M. Random amplified polymorphic DNA (RAPD) typing of necrophageous insects (Diptera, Coleoptera). Criminal forensic studies: validation and use in practice. Forensic Science International, [S.l], n. 98, p. 157-168, 1998.

BENECKE, M. A brief history of forensic entomology. Science International, [S.l], n. 120 , p. $2-14,2001$.

BORROR, D.J.; DELONG, D.M. Introdução ao estudo dos insetos. São Paulo: E. Bücher, 1969.

DADOUR, I.R.; et. al. Forensic entomology: application, education and research in Western Australia. Forensic Science International, [S.1], n. 120, p. 48-52, 2001.

GRASSBERGER, M.; REITER, C. Effect of temperature on Lucilia sericata (Diptera: Calliphoridae) development with special reference to the isomegalenand isomorphen- diagram. Forensic Science International, [S.1], n. 120, p. 32-36, 2001.

GRASSBERGER, M.; REITER, C. Effect of temperature on development of the forensically important holartic blow fly Protophormia terraenovae (RobineauDesvoidy) (Diptera: Calliphoridae). Forensic Science International, [S.l], n. 128, p. 177-182, 2002a.

GRASSBERGER, M.; REITER, C. Effect of temperature on development of Liopygia (= Sarcophaga) argyrostoma (Robineau-Desvoidy) (Diptera: Sarcophagidae) and its Forensic Implications. Journal of Forensic Science, [S.1], n.47, v.6, p. 2002 b.

GRIFFITHS, A.J.F.; et. al. Genética moderna. Guanabara Koogan: Rio de Janeiro, 2001.

HARVEY, M.L.; DADOUR, I.R.; GAUDIERI, S. Mitochondrial DNA cytochome oxidase I gene: potential for distinction between immature stages of some forensically important fly species (Diptera) in Western Australia. Forensic Science International, [S.l], n. 131, p. 134-139, 2003.

JUNQUEIRA, A.C.M. et al. The mitochondrial genome of blowfly Chrysomya chloropyga (Diptera: Calliphoridae). Forensic Science International, [S.l], n. 339, p. 7-15, 2004.

KULSHRESTHA, P.; SATPATHY, D.K. Use of beetles in forensic entomology. Forensic Science International, [S.1], n. 120, p. 15-17, 2001. 
LIMA, L.H.C.; et. al. Survey of Bemisia tabaci (Gennadius) (Hemiptera: Aleyrodidae) biotypes in Brazil using RAPD markers. Genetics and Molecular Biology, [S.l], n. 4, v. 23, p. 1-5. 2000.

MALGORN, Y.; COQUOZ, R. DNA typing for identification of some species of Calliphoridae an interest in forensic entomology. Forensic Science International, [S.l], n. 102, p. 111-119, 1999.

MARCHENKO, M.I. Forensic Medicolegal reference of cadaver entomofauna for the determination of the time of death. Forensic Science International, [S.1], n. 120, p. 89-109, 2001.

MONNERAT, R.G.et al. Variabilidade Genética do Parasitóide Diadegma sp. através de RAPD-PCR. Horticultura Brasileira, [S.1], n. 22, v.1, p. 90-92, 2004.

QUEIROZ, P.R. et al. Análise da variabilidade de uma população de Spodoptera frugiperda (J.E. SMITH, 1797) (Lepidoptera: Noctuidae) por meio de marcadores moleculares RAPD. Boletim de Pesquisa e Desenvolvimento, [S.1], n. 75, p. 18, 2004 .

STEVENS, J.; WALL, R. Genetic relationships between blowflies (Calliphoridae) of forensic importance. Forensic Science International, [S.1], n. 120, p. 116-123, 2001.

TURCHETTO, M.; LAFISCA, S.; COSTANTINI, G. Postmortem interval (PMI) determiner by study sarcophagous biocenoses: three casas from the province of Venice (Italy). Forensic Science International, [S.l], n. 120, p. 28-31, 2001.

VIANNA, E.E.S. et al. Abundancia e flutuação populacional das espécies de Chrysomya (Diptera, Calliphoridae) em Pelotas, Rio Grande do Sul, Brasil. Iheringia, [S.1], n. 94, v. 3, p. 231-234, 2004.

WALLMAN, J.F.; DONNELLAN, S.C. The utility of mitochondrial DNA sequences for identification of forensically important blowflies (Diptera: Calliphoridae). In southeastern Australia. Forensic Science International, [S.1], n. 120, p. 60-67, 2001.

WELLS, J.D.; SPERLING, F.A.H. DNA-based identification of forensically important Chrysomyinae (Diptera: Calliphoridae). Forensic Science International, [S.1], n. 120, p. $110-115,2001$.

WOLFF, M.; URIBE, A.; ORTIZ, A.; DUQUE, P. A preliminary study of forensic entomology in Medellín, Colombia. Forensic Science International, [S.1], n. 120, p. 53-59, 2001. 